\title{
Discrepancies between the one- and two-stage prothrombin estimations in purified prothrombin preparations
}

\author{
Citation for published version (APA): \\ Hemker, H. C., \& Muller, A. D. (1975). Discrepancies between the one- and two-stage prothrombin \\ estimations in purified prothrombin preparations. In H. C. Hemker, \& J. J. Veltkamp (Eds.), Prothrombin \\ and Related Coagulation Factors (pp. 89-92). Springer. Boerhaave Series for Postgraduate Medical \\ Education Vol. 10
}

Document status and date:

Published: 01/01/1975

\section{Document Version:}

Publisher's PDF, also known as Version of record

\section{Please check the document version of this publication:}

- A submitted manuscript is the version of the article upon submission and before peer-review. There can be important differences between the submitted version and the official published version of record. People interested in the research are advised to contact the author for the final version of the publication, or visit the DOI to the publisher's website.

- The final author version and the galley proof are versions of the publication after peer review.

- The final published version features the final layout of the paper including the volume, issue and page numbers.

Link to publication

\footnotetext{
General rights rights.

- You may freely distribute the URL identifying the publication in the public portal. please follow below link for the End User Agreement:

www.umlib.nl/taverne-license

Take down policy

If you believe that this document breaches copyright please contact us at:

repository@maastrichtuniversity.nl

providing details and we will investigate your claim.
}

Copyright and moral rights for the publications made accessible in the public portal are retained by the authors and/or other copyright owners and it is a condition of accessing publications that users recognise and abide by the legal requirements associated with these

- Users may download and print one copy of any publication from the public portal for the purpose of private study or research.

- You may not further distribute the material or use it for any profit-making activity or commercial gain

If the publication is distributed under the terms of Article $25 \mathrm{fa}$ of the Dutch Copyright Act, indicated by the "Taverne" license above, 


\title{
In: Prothrombin and Related Coagulation factors Edited by H.C. Hemker and Y.Y. Velthamp igys pp. $8 g-g_{2}$
}

\author{
DISCREPANCIES BETWEEN THE ONE- AND TWO-STAGE \\ PROTHROMBIN ESTIMATIONS IN PURIFIED \\ PROTHROMBIN PREPARATIONS
}

H. C. HEMKER AND A. D. MULLER

Recently, Kisiel and Hanahan (1) reported a method to purify prothrombin. In the purified product a discrepancy was observed between the onestage and the two-stage determination. The same phenomenon has been observed by other investigators (2). We tried to find the cause of this discrepancy and we think that in the light of the results reported by Stenflo (3) (this volume, ref. 3 ) we can offer a hypothesis to explain it.

In previous work we investigated the kinetic mechanism at the basis of the one-stage and the two-stage prothrombin determinations (4-6).

All prothrombin determinations are based upon thrombin generation. Thrombin generation in the absence of antithrombins has a time course as depicted in figure 1 . The initial velocity of thrombin generation $(\alpha)$ levels off to approach zero when all prothrombin has been converted into thrombin. The amount of thrombin then formed $(\beta)$ of course reflects the amount of prothrombin originally present.

In a one-stage test $\alpha$ is measured, in a two-stage test one determines $\beta$. In both tests normal plasma is used as a standard. $\alpha$ and $\beta$ are interdependent. When this interdependancy in a preparation is the same as it is in normal plasma by definition no differences will be found between the one and the two-stage determination. When on the other hand a certain type of prothrombin is converted at a slower rate than normal prothrombin (d in fig. 1) but eventually produces the same final amount of thrombin $(\sim 50 \mathrm{U} / \mathrm{ml}$ in fig. 1) one will estimate a low level in the one-stage and a normal one in the two-stage. This is what is actually observed with PIVKA-II (7). We determined the thrombin generation curve of four types of preparation: a) A euglobulin precipitate from normal plasma; b) a preparation of prothrombin prepared according to a method developed in our laboratory using the selective effect of Cd-ions upon the adsorbtion of prothrombin onto $\mathrm{Al}(\mathrm{OH})_{3}$ $(8,9)$; c) a preparation of prothrombin prepared according to Kisiel 


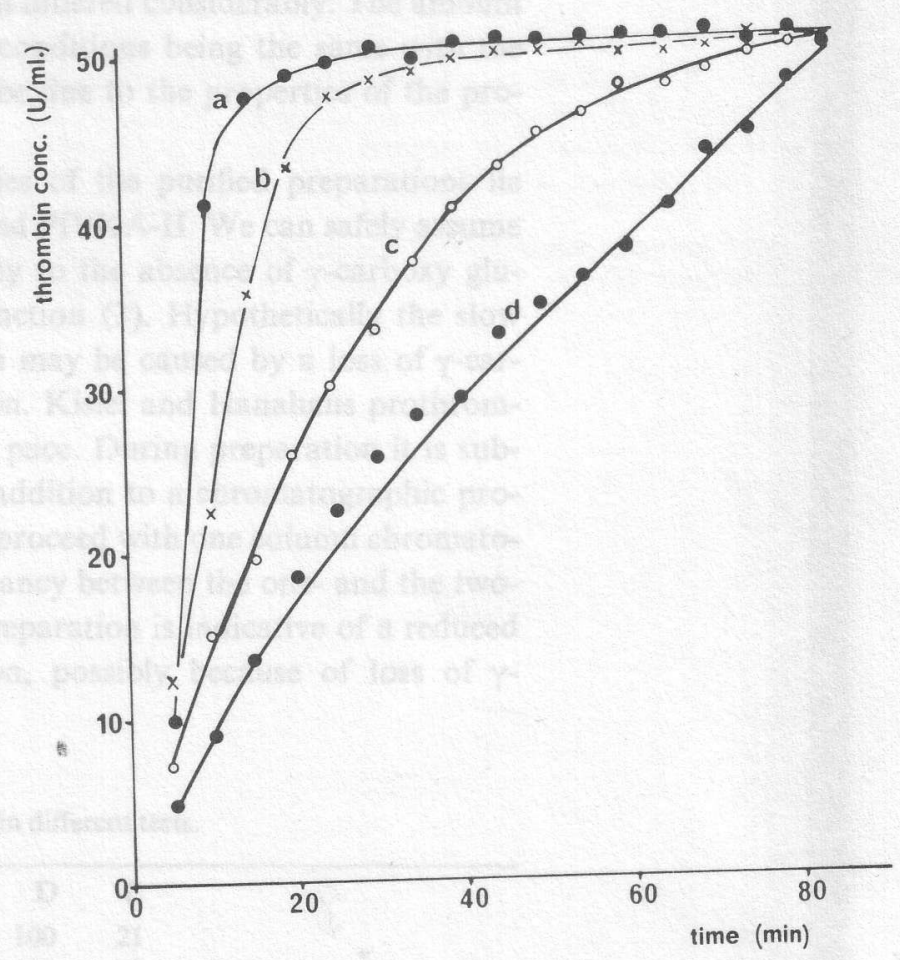

Fig. 1. Time course of thrombin generation. At zero time a fixed high amount of prothrombinase is added to a prothrombin preparation. The incubation is done at $37^{\circ} \mathrm{C}$. At $2 \mathrm{~min}$. intervals $0.1 \mathrm{ml}$ aliquots of the incubation mixture are assayed for their thrombin content.

a : normal plasma (euglobulin preparation)

b : prothrombin preparation prepared according to ref. 8 .

c : prothrombin preparation prepared according to ref. 1.

$\mathrm{d}$ : plasma from patients under deep oral anticoagulation.

and Hanahan and d) a euglobulin preparation from plasma of a deeply anticoagulated patient. Care was taken to add a fixed high amount of prothrombinase at zero time.

One would like to do this type of experiments with native prothrombin, but untreated plasma cannot be used because of the antithrombin 3 present in it. We therefore used a euglobulin precipitate, i.e. a preparation where the prothrombin went through only one purification step viz. acid precipitation. We adjusted the dilutions of the different preparations so that eventually the same amount of thrombin was formed. 
The initial rates of thrombin formation differed considerably. The amount of prothrombinase as well as all other conditions being the same with the four preparations, the differences must be due to the properties of the prothrombin present.

We observe that the kinetic properties of the purified preparations lie between those of normal prothrombin and PIVKA-II. We can safely assume that PIVKA-II owes its aberrant activity to the absence of $\gamma$-carboxy glutamyl residues necessary for normal function (3). Hypothetically the slow conversion of the purified prothrombins may be caused by a loss of $\gamma$-carboxy glutamyl groups during preparation. Kisiel and Hanahans prothrombin generates thrombin at a rather slow pace. During preparation it is subjected to preparative electrophoresis in addition to a chromatographic procedure whereas in our procedure we can proceed with one column chromatography only. We conclude that a discrepancy between the one- and the twostage determination in a prothrombin preparation is indicative of a reduced specific velocity of thrombin generation, possibly because of loss of $\gamma$ carboxy glutamyl groups.

Table 1. Comparison of different prothrombins in different tests.

\begin{tabular}{lccccc}
\hline & A & B & C & D & E \\
one-stage & 100 & 100 & 100 & 100 & 21 \\
two-stage & 72 & 60 & 97 & 100 & 43 \\
initial velocity & 1,2 & - & 2,7 & 3,4 & 0,8
\end{tabular}

The activities are expressed in $\%$ of normal plasma, the initial velocity as $U$ of thrombin per minute.
A : prothrombin prepared according to Kisiel and Hanahan as estimated in our labor- atory
B : the same, calculated from the author's results (1)
C : prothrombin prepared according to Devilee (8), (9)
$\mathrm{D}$ : normal plasma
E : plasma from a patient receiving dicoumarol.

\section{REFERENCES}

1. Kisiel, W. and D. J. Hanahan, Biochem. biophys. Acta 304, 103-113 (1973).

2. Josso, F., Personal communication.

3. Stenflo, J., P. Farmlund, W. Egen and P. Roapstorf, Proc. nat. Acad. Sci. 71 2730-2733 (1974).

4. Hemker, H. C., A. C. W. Swart and A. J. M. Alink, Thrombos. Diathes. haemorrh. 27, 205-211 (1972). 
5. Hemker, H. C., P. W. Hemker, K. van der Torren, P. P. Devilee, W. Th. Hermens and E. A. Loeliger, Thrombos. Diathes. haemorrh. 25, 545-554 (1971).

6. Hemker, H. C. and P. W. Hemker, Proc. roy. Soc. B 173, 411-420 (1969).

7. Hemker, H. C., A. D. Muller and E. A. Loeliger, Thrombos. Diathes. haemorrh. 23, 633-637 (1970).

8. Devilee, P. P., B. M. Bas and H. C. Hemker, Biochom. bioph. Acta 379, 172-179 (1975).

9. Devilee, P. P., J. S. de Graaf and J. M. van der Voort-Beelen, B. M. Bas. This volume p. 93-98. 